\title{
大腸多発癌症例の検討
}

岐阜市民病院外科
竹腰 知治 田中 千凱 伊藤 隆夫
松村幸次郎

同 病理検查部

加地 秀 樹

\section{CLINICOPATHOLOGICAL STUDIES ON MULTIPLE CARCINOMAS OF COLON AND RECTUM}

\author{
Tomoharu TAKEKOSHI, Sengai TANAKA, Takao ITO \\ and Kojiro MATSUMURA
}

Department of Surgery, Gifu City Hospital

\section{Hideki KACHI}

Department of Pathology, Gifu City Hospital

1972 1982年の間に, 大腸癌324症例中, 同時性17症例, 異時性 1 症例の大腸多発癌18症例を経験乙 た. 頻度は $5.6 \%$ で性比は同時性で男対女，7：10で異時性の 1例は女性であった. 発生部位は同時性, 異時性とも直腸領域に多かった，同時性第 2 癌は第 1 癌に比較して進行度は低かった．同時性多発癌 では進行癌と早期癌の組み合わせが11例 $(61.1 \%)$ 之高く, 早期癌が進行癌より口側にある時正診率 が低いことより，術前，中，後にわたる精査の必要性が示唆され，さらに同時性多発癌に同時性重複 癌 (胃) を併存した 1 症例を経験したことより他臓器の十分な精査の必要性も示唆された。治瘾切除 できた同時性, 異時性多発癌の予後は良好であった。

索引用語：大腸多発癌

近年本邦において，大腸癌の增加は著明であり，平 山息は西暦2000年には筆頭癌になると予測されると述 べている，当院においても症例数の增加に伴い，同時 性および, 異時性大腸多発癌を経験する機会が多く なった，今回私達は1972１982年の11年間に経験した 大腸多発癌について検討したので報告する。

\section{I. 対 象}

1972 1982年の11年間の当院外科で経験した大腸癌 は324例で，切除症例は272例であった。このうち大腸 単発癌は306例, 多発癌（大腸ポリポージス症を除く） は同時性多発癌17例, 異時性多発癌 1 例の計18例で あった。大腸多発癌の定義は Moertel ${ }^{2}$ の判定基準に 従ったが, 私達は北條ら ${ }^{3)}$ と同じく, 第 1 癌〜第 2 癌ま

$<1984$ 年11月 6 日受理 $>$ 別刷請求先：竹腰 知治

干500 岐阜市鹿島町 7-1 岐阜市民病院外科
での期間が 1 年未満を同時性多発癌， 1 年以上を異時 性多発癌とした。さらに同時性多発癌に対して，大腸 癌取扱い規約) に従いその局在部位を 9 つの領域にわ け，同領域に多発したものを同所性多発癌とし，異な る領域に多発したものを異所性多発癌とした。

\section{II. 成 績}

1) 頻度

大腸多発癌18例は全症例324例に対し5.6\%を占め た.さらに18症例全例が切除できたので切除例 272 例に 対し6.6\%となった。そのうち同時性多発癌17例は 6.3\%を，異時性多発癌は $0.3 \%$ を占めた（表 1 ）。

2）性別执よび平均年齢

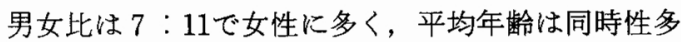
発癌で男 62.3 歳，女61.6歳となり男性の方が若干高齢 であった。（表 2).

3) 病巣数 
表 1 大腸多発癌症例

\begin{tabular}{|c|c|c|c|c|c|c|c|}
\hline 1972 1962年 & \multirow{2}{*}{\multicolumn{3}{|c|}{ 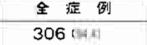 }} & \multirow{2}{*}{\multicolumn{2}{|c|}{ 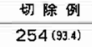 }} & \multirow{2}{*}{\multicolumn{2}{|c|}{$\frac{\text { Ant this }}{52}$}} \\
\hline 単発器 & & & & & & & \\
\hline \multirow{2}{*}{ 多器 } & 同晊 & $17 \div 11$ & \multirow{2}{*}{$\begin{array}{l}18 \\
(56)\end{array}$} & $17(6.3)$ & \multirow{2}{*}{$\begin{array}{c}18 \\
(6.5)\end{array}$} & 0 & \multirow{2}{*}{0} \\
\hline & 其明推 & ilont & & $1(0.3)$ & & 0 & \\
\hline ist & \multicolumn{3}{|c|}{$324(100)$} & \multicolumn{2}{|c|}{$272(100)$} & \multicolumn{2}{|c|}{52} \\
\hline
\end{tabular}

表 2 大腸多発癌症例の性別，平均年齢

\begin{tabular}{|c|c|c|c|}
\hline & in & pist & 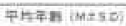 \\
\hline \multirow{2}{*}{ 两击世 } & $n$ & 7 & $62.3 \neq 7.8$ \\
\hline & \# & 10 & $61.6=10.9$ \\
\hline 贾的击 & \pm & 1 & $710^{\circ}$ \\
\hline
\end{tabular}

総病巣数は41個で, 5ち同時性多発癌が39個, 異時 性多発癌が 2 個であった，そのうち病巣数 2 個が，同 時性多発癌13例, 異時性多発癌 1 例あり, 計14例 (77.8\%) を占めた。病单数 3 個が 3 例（16.7\%），病 巣数 4 個が 1 例 (5.5\%) であった（表 3).

4) 占拠部位

同時性同所多発癌は11例（26病巣）を認め, 同時性 多発癌17例の $64.7 \%$ 占めた. 部位は $\mathrm{Rb} の 4$ 例, $\mathrm{T} の$ 2 例, 以下 $\mathrm{Ra}, \mathrm{Rs}, \mathrm{D}, \mathrm{A}, \mathrm{C}$ の各々 1 例で $\mathrm{Rb}$ が最子 多かった。同時性異所多発癌は6 例 (13病巣) で同時 性多発癌の $35.3 \%$ 占めた。隣接領域に発症したもの は P-Rb, T-A の 2 例, 1 領域離れたものは Rb-Rs, D. $\mathrm{A}, \mathrm{T}-\mathrm{C}$ の 3 例, 3 領域離れたものは S-Cの 1 例であ。

表 3 大腸多発癌の癌腫個数

\begin{tabular}{|c|c|c|c|c|c|}
\hline 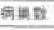 & & $2 \sqrt{14}$ & 3何 & 4 all & if \\
\hline exist & 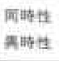 & $\left.\begin{array}{c}13 \\
1\end{array}\right\}$ thes & $\left.\begin{array}{l}3 \\
0\end{array}\right\}_{(t \in)}^{3}$ & $\left.\begin{array}{l}1 \\
0\end{array}\right\}_{(53)}^{1}$ & $\int_{100}^{17}$ \\
\hline का & 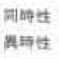 & 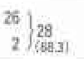 & $\int_{0}^{9}$ & $\left.{ }_{0}^{4}\right\}_{(4,7)}^{4}$ & $\left.\frac{39}{2}\right\}_{100}^{41}$ \\
\hline
\end{tabular}

表 4 大腸多発癌の占拠部位

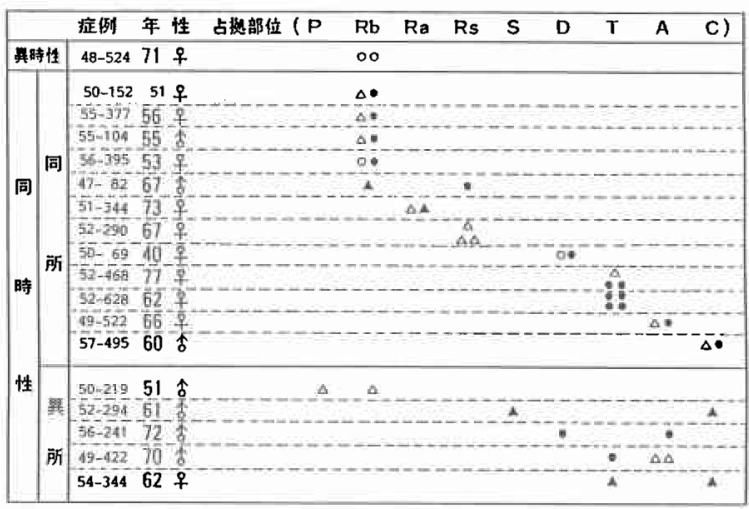

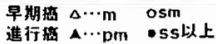

た.

異時性同所多発癌は $\mathrm{Rb}$ に発生した 1 例のみであっ た（表 4 ）.

5) 病理組織学的所見

多発癌について同時性は壁深達度がより高度のもの を，また同一の場合は腫瘍径の大きいものを第 1 癌と し，異時性では最初のものを第 1 癌とした上で病理組 織学的検討を加えた.

a）壁深達度

壁深達度でみると進行癌23個, 早期癌18個の割合で あった，その症例別組み合わせは, 進行癌と進行癌が 5 例 $(27.8 \%)$, 進行癌と早期癌が11例 (61.1\%), 早 期癌と早期癌が 2 例 (11.1\%) となり進行癌と早期癌 の組み合わせが最も多かった。また進行癌は第 1 癌に 多く，18例中15例 $(82.2 \%$ ) を占め，早期癌は第 2 癌 18 例中 12 例 $(66.7 \%)$, 第 3 癌に 4 例中 3 例 $(75 \%)$ と 第 2 癌以下に多い傾向が認められた（表 5 ).

b) 組織型

組織型でみると高分化型32個，中分化型 9 個で，低 分化型および粘液型は認められなかった，症例別の組 み合わせでみると, 高分化型と高分化型が10例 (55.6\%)，高分化型と中分化型が 7 例(38.9\%)，中分 化型と中分化型が 1 例 $(5.5 \%)$ の順となり，高分化型 と高分化型との組文合わせが最も多かった。 また中分 化型は第 1 癌に 6 例 $(33.3 \%)$ と多く，高分化型は第 2 癌に 15 例 $(83.3 \%)$, 第 3,4 癌では全例と, 第 2,3 , 4 癌に多くなる傾向が認められた（表 6 ）.

\section{表 5 大腸多発癌の組み合わせと組織学的壁深達度}

\begin{tabular}{|c|c|c|c|c|c|c|c|}
\hline & & \multicolumn{2}{|c|}{ 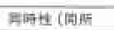 } & \multicolumn{2}{|c|}{ 要第? } & 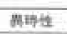 & it \\
\hline \multicolumn{2}{|c|}{ 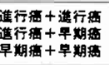 } & & $\begin{array}{r}1 \\
10 \\
1\end{array}$ & $\begin{array}{l}4 \\
1 \\
0\end{array}$ & & $\begin{array}{l}0 \\
0 \\
1\end{array}$ & $\begin{array}{r}5(27.8) \\
11(61.1) \\
2(11.1)\end{array}$ \\
\hline \multicolumn{2}{|r|}{ it } & \multicolumn{2}{|c|}{$12(66.7)$} & & (27.8) & $1(5.5)$ & $18[(x)$ \\
\hline & $\mathrm{m}$ & sm & $\mathrm{Dm}$ & $5 s\left(a_{i}\right)$ & $s\left(\theta_{t}\right)$ & si & it \\
\hline 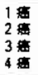 & $\begin{array}{l}2 \\
9 \\
3 \\
0\end{array}$ & $\begin{array}{l}1(1) \\
3(1) \\
0 \\
0\end{array}$ & $\begin{array}{l}2 \\
3 \\
0 \\
0\end{array}$ & $\begin{array}{l}6 \\
2 \\
1 \\
1\end{array}$ & $\begin{array}{l}6 \\
1 \\
0 \\
0\end{array}$ & $\begin{array}{l}1 \\
0 \\
0 \\
0\end{array}$ & $\begin{array}{r}18(43.9) \\
18(43.9) \\
4(9.8) \\
1(2.4)\end{array}$ \\
\hline It & $14(34,1)$ & $4(9.8)$ & $5(12.2) 1$ & $10\{24,4$ & 4) $7(17.1$ & $7.1) \quad 1(2$ & .5) $41(100)$ \\
\hline
\end{tabular}

表 6 大腸多発癌の組織型

\begin{tabular}{|c|c|c|c|c|c|c|}
\hline & & \multicolumn{2}{|c|}{ 同時性(同所 } & \multirow{2}{*}{$\begin{array}{c}\text { 異所) } \\
2 \\
2 \\
0\end{array}$} & \multirow{2}{*}{$\begin{array}{l}\text { 基時性 } \\
0 \\
1 \\
0\end{array}$} & \multirow{2}{*}{$\begin{array}{l}\text { 8f } \\
10(55.6) \\
7[3.9] \\
1[5.5]\end{array}$} \\
\hline 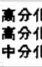 & 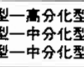 & & $\begin{array}{l}8 \\
4 \\
1\end{array}$ & & & \\
\hline & Ht & \multicolumn{2}{|c|}{$13(72.2)$} & 2) $4[22.2]$ & $1(5.6]$ & $18(100)$ \\
\hline & 高分化型 & 中分化型 & 讧 低分 & 分化型 & muci & gt \\
\hline 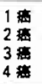 & $\begin{array}{l}12(11 \\
15 \\
4 \\
1\end{array}$ & $\begin{array}{l}6 \\
3(1) \\
0 \\
0\end{array}$ & & $\begin{array}{l}0 \\
0 \\
0 \\
0\end{array}$ & $\begin{array}{l}0 \\
0 \\
0 \\
0\end{array}$ & $\begin{array}{r}18(43.9) \\
18(43.9) \\
4[9.8] \\
1(2.4)\end{array}$ \\
\hline It & $32(78.0)$ & $9(22.0)$ & & 0 & a & 41 (10) \\
\hline
\end{tabular}


c）脈管侵襲

脈管侵襲でみると静脈侵襲は第 1 癌で陽性率 $38.9 \%$, 第 2 癌 $22.2 \%$, 第 3,4 癌 $0 \%$ 之なり第 1 癌が 最も高かった。リンパ管侵襲では，第 1 癌が $72.2 \%$, 第 2 癌 $50 \%$, 第 3 癌 $25 \%$ と第 1 癌の陽性率が最も高 かった。（表 7 ).

6) ポリープの併存

ポリープ併存例は 2 多発癌14例中 4 例 $(28.6 \%), 3$ 多発癌 3 例中 2 例 $(66.7 \%$ ) に認められ全体として 6 例（33.3\%）に認められた。 またポリープを伴う6 例 で cancer in adenoma を認めたものが 4 例 (66.7\%) あったが，ポリープを伴わない12例には 3 例（25\%） しか認められなかった（表 8 ）.

\section{表 7 大晹多発癌の脈管侵襲}

\begin{tabular}{|c|c|c|c|c|c|c|}
\hline & $v_{a}$ & $V_{1}$ & $v_{i}$ & $v_{n}$ & 尔积 & It \\
\hline 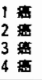 & $\begin{array}{r}10 \\
14 \\
4 \\
1\end{array}$ & $\begin{array}{l}7 \\
2\end{array}$ & $2(11$ & & 1(1) & $\begin{array}{r}18[43.9] \\
18(43.9] \\
4(9.8] \\
1(2.4)\end{array}$ \\
\hline \multirow[t]{2}{*}{80} & $29[70.7]$ & $9\{22.0\}$ & $2(4.9)$ & & $1(2.4)$ & $141(100)$ \\
\hline & $1 y_{0}$ & $\mid y_{1}$ & $\mid y_{2}$ & $\mid y_{3}$ & 不明 & It \\
\hline 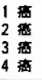 & $\begin{array}{l}4 \\
9 \\
3 \\
0\end{array}$ & $\begin{array}{l}7 \\
4(1) \\
0 \\
0\end{array}$ & $\begin{array}{l}6 \\
5 \\
1 \\
1\end{array}$ & $\begin{array}{l}0 \\
0 \\
0 \\
0\end{array}$ & (11) & $\begin{array}{r}18[43.9] \\
18[43.9] \\
4(9.8) \\
1(2.4)\end{array}$ \\
\hline tit & $16(39.4)$ & $11(26.8]$ & $13[31.8]$ & 0 & $1\{2.4]$ & $41(100)$ \\
\hline
\end{tabular}

表 8 大腸多発癌とポリープとの関係

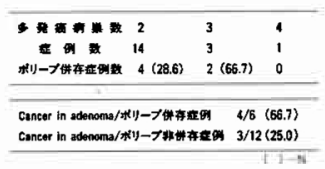

\section{7) 診断}

同時性多発癌17例中術前に多発癌と正診できた症例 は 5 例 $(29.4 \%)$ であった：詳細に検討してみると， 進行癌と進行癌の組み合わせ 5 例では術前 3 例で正診 率60.0\%であった。 2 例の正診できなかった理由は， 注腸検査で 1 例が 1 領域（DとA）はなれていたため 見落したのと，1例はあまりにも近接していたため単 発癌とみなしたためであった。

進行癌と早期癌の組み合わせ11例は術前に正診でき たものは 2 例で $18.2 \%$ 正診率であった。その 2 例は 早期癌が進行癌より肛門側にあった 3 例の内の 2 例で あった，早期癌が進行癌より口側に位置した 8 例は正 診率 $0 \%$ で,このような症例の正診率の向上が必要と 思われた。さらに同時性多発癌 1 症例に，胃の同時珄 重複癌 (por. schirrous type ssr. $\mathrm{P}_{0} \mathrm{H}_{0} \mathrm{n}_{0}$ stage II) を術前に診断したことより他臓器への注意も必要と思 われる(表 9 ).

8）治療と予後

表 9 正診例の検討

\begin{tabular}{|c|c|c|}
\hline & 正診例 $(\%)$ & 嘼診例（\%） \\
\hline 進行癌↔進行癌 & $3(60.0)$ & $2(40.0)$ \\
\hline 進行癌↔早期癌 & $2(18.2)$ & $9(81.8)$ \\
\hline [ 口側が進行澏の時 & $2(66.6)$ & $1(33.4)]$ \\
\hline [肛門側が進行癌の時 & $0(0)$ & $8(100.0)]$ \\
\hline 早期癌↔早期癌 & $0(0)$ & $1(100.0)$ \\
\hline 全 例 & $5(29.4)$ & $12(70.6)$ \\
\hline
\end{tabular}

表10 大腸多発癌の治療と予後

\begin{tabular}{|c|c|c|c|c|c|c|c|}
\hline 症 例 & 年, 性 & 部位 & stage & 術 & 術 & 根治度 & 予後 (S.57.12.31現在) \\
\hline 1) K.H. & 71 우 & $\mathrm{Rb}$ & I & & & 滰 & 7 年生存 \\
\hline 2) T.Y. & $\overline{71} \overline{+}$ & $\mathrm{Rb}$ & $\overline{I V}$ & 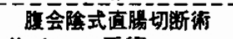 & & 治 & 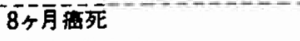 \\
\hline 3) $1 . \mathrm{T}$. & 56 우 & $\mathbf{R a}, \mathbf{R b}$ & III & 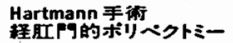 & $\begin{array}{l}\text { S55.7.31 } \\
\text { s55.11.17 }\end{array}$ & 渻 & 2年1ヶ月生存 \\
\hline 4) T.Y. & $55 \hat{\jmath}$ & $\mathrm{Rb}$ & II & 腹会陰式直满切断衡 & 555.2 .13 & 治 & 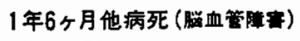 \\
\hline 5) Y.F. & $53+$ & $\mathbf{R b}$ & II & 腈会陰式值腈切断行 & S56. 8. 5 & 治 & 1年4ヶ月生存 \\
\hline 6) H.G. & $67 \hat{8}$ & Rb, Rs & II & 腹会陵式直腈切断術 & S47. 2.8 & 治 & 7ヶ月然死 \\
\hline 7) H. K. & $73+9$ & $\mathbf{R a}$ & III & 前方切 除 術 & s51. 7.14 & 治 & 5年6ヶ月他病死（心疾憲） \\
\hline 8) I.Y. & $67 \%$ & Rs & I & 開凌ボリペクトミー & S52. 5.26 & 治 & 5年7ヶ月生存 \\
\hline 9) N.M. & $40+9$ & D & III & 左半結㬓切除衔 & s50. 1.27 & 治 & 6年11ヶ月生存 \\
\hline 10) K.T. & 77우 & $\mathbf{T}$ & II & 右半結䭪切除術 & 552. 9. 8 & 治 & 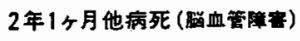 \\
\hline 11) H.M. & $62 \%$ & $\mathbf{T}$ & $\mathbf{V}$ & 結腈部分切除御 & $\begin{array}{l}552.12 .20 \\
553.6 .21\end{array}$ & $\begin{array}{c}\text { 翡 } \\
\text { 我 }\end{array}$ & 6ヶ月宓死 \\
\hline 12) M.T. & 66 우 & A & III & 右半結腸切除術 & $\$ 49.11 .6$ & 治 & 5年6ヶ月病死 \\
\hline 13) H. T. & $60 \hat{\delta}$ & C & III & 右半結腸切除術 & $S 57.11 .22$ & 治 & 2ヶ月生存 \\
\hline 14) H. T. & $51 \hat{\delta}$ & $\mathbf{R b}, \mathbf{P}$ & $\mathbf{I}$ & 胶会陵式直腸切断街 & S50. 4.23 & 治 & 6 年8ヶ月生存 \\
\hline 15) $T . Y$. & $61 \delta$ & S. C & II & 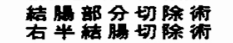 & $\begin{array}{l}\text { S52. } 5.26 \\
\text { s53. } 4.27\end{array}$ & 治 & 4 年8ヶ月生存 \\
\hline 16) H.Y. & $72 \hat{\delta}$ & A. D & III & 全結腸切除街 & 556.4 .23 & 治 & 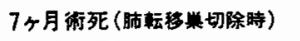 \\
\hline 17) U.K. & $70 \hat{\delta}$ & T. A & II & 右半結腸切除街 & S49. 8.29 & 治 & 4 年6ヶ月癌死 \\
\hline 18) Y.T. & 62 우 & c. $T$ & I & 右半結腸切除衙 & s54. 7.18 & 治 & 3年5ヶ月生存 \\
\hline
\end{tabular}


治療は18例に対しのべ22回の手術が施行された。そ のらち polypectomy は 2 例に対し 3 回行われたのに すぎず，他は全例切除された，切除術式として右拈よ び左半結腸切除術の 7 例に対しのべ 7 回が最も多く, つぎに腹会陰式直腸切断術が 5 例に対し 5 回行われ， 以下結腸部分切除扣よびその他の順となった，治瘜切 除は18例中17例（94.4\%）に行われた。また予後子治 瘷切除できたものについては良好であった（表10）。

\section{III. 考 案}

大腸多発癌の頻度は北條 ${ }^{3)}$ が5.6\%, 加藤 5 が $6.0 \%$, 高島 ${ }^{6)}$ か $5.4 \%$ ，近藤 ${ }^{7}$ が $5.9 \%$ と報告している．その平

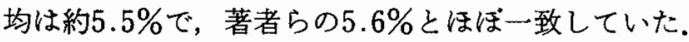
同時性多発癌々異時性多発癌との割合は，著者らと同 じく第 1 癌との第 2 癌との発現間隔を 1 年を境にして 区別している北條ら ${ }^{3 / 4} 3: 1$, 近藤らフは $6: 1$ と報 告しているが，著者らは17：1 と同時性が著明に高 かった．性別分布は男性に多(、3)5 〜10) とする報告があ るが，自験例では男女比 7：11と女性に多かった，発 病年齢は同時性で男女間に差は認められなかった，病 巣数については 2 個が最も多く同時性17例中13例 （76.5\%）を占め，次に 3 個， 4 個の順で，近藤ら 2 個 $83.3 \%$ ，3 個 $12.5 \% ， 4$ 個4.2\%と注致してお り大きな差異は認められなかった。

占拠部位は多発癌に沶いて S 状結腸に多いといら報 告2)7) と，直腸に多いという報告9)の両説があるが，自験 例では18例中 7 例 $(38.9 \%)$ 之直腸領域に発生したも のが最も多く，S 状結腸領域が関与したものは 1 例と 少ないのが特改的であった。 また第 1 癌および第 2 癌 が同一領域怙よび隣接領域に発症したものは18例中14 例 (77.8\%) と最も多く，その割合とMoertel ${ }^{2}$.

友田 ${ }^{10)}$, 富田 ${ }^{11)}$, 近藤ら ${ }^{7)}$ と比較して著明に高く特徵 的であった。 また 1 領域以上離れた症例は全例同時性 多発癌で17例中 4 例 $(23.5 \%)$ を占め, 術前に大腸全 体に亘る䄸密な検索が必要と思われた。

診断についてみると，同時性多発癌17例中術前に正 診できたものは 5 例であった。これを検討すると進行 癌一進行癌の組み合わせの時は $60.0 \%$ 正診率であっ た。しかし進行癌と早期癌の組み合わせの場合，特に 早期癌が進行癌より口側に位置する症例が術前精查不 十分のことが多いため，これらの正竛率は低くなり， 全体として正診率が低くなった。これらの正診率向上 のため術前の大腸全般に亘る精查, 術中の用手的検查,

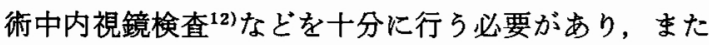
ileusなどで緊急手術を施行する場合には, 術中の検索
はもとより，術後残大腸の精査が必要である。

また同時性多発癌に胃の同時性重複癌を合併した症 例が 1 例あり他藏器の十分な検索も必要である。

異時性多発癌は予後良好との報告5)6)8 多多く，自験 例も同様であった，同時性多発癌でも治療切除できた 症例の予後は良好であった。

\section{IV. 結 語}

最近の 11 年間に経験した大腸多発癌18例について検 討を加え以下の結果を得た。

（1）頻度は5.6\%であった。同時性多発癌17例, 異時 性多発癌 1 例であった。

（2）性比では同時性多発癌で男：女 $=7: 11$ であ り, 異時性多発癌の 1 例子女性で, 多発癌は女性に多 い傾向がみられた。

3）発生部位は, 同時性多発癌では直腸領域に高頻度 に発生した，異時性多発癌も直腸領域であった。

（4）ポリープ併存例に cancer in adenoma が多い 傾向が認められた。

（5）同時性多発癌で，進行癌と早期癌の組み合わせ が11例（61.1\%）と高いため，術前，中，後にわたる 十分な検索の必要性が示された。

（6）同時性多発癌に同時性重複癌（胃）を併存した 1 症例を経験したことょり他藏器の十分な検索の必要 性が示唆された。

7）治瘾切除できたものは, 同時性, 異時性多発癌と も予後は良好であった。

本論文の要旨は第23回日本消化器外科学会総会 (宇部市) に括いて発表した。

\section{文献}

1）平山 雄：大腸癌の疫学的変遷々今後の展望. 日 臨 39:2006-2016, 1981

2) Moertel CG, Bargen JA, Dockerty MB : Multiple carcinomas of the large intestine. A review of the literture and a study of 261 cases. Gastroenterology $34: 85-98,1958$

3）北條慶一, 小山靖夫, 伊藤一二：大腸重複癌. 外科 $33: 1255-1262,1971$

4）大腸癌研究会編：臨床病理. 大腸癌取扱い規約. 改 訂第 3 版．金原出版，東京，1983

5）加藤知行, 山内晶司, 森本剛司ほか：大腸の多発 癌. 外科診療 $23: 214-221,1981$

6）高島茂樹, 桐山正人, 富山富士夫ほか：大腸多発癌 の臨床病理学的検討：同時性と異時性の対比か 5. 外科診療 $25: 193-199,1983$

7）近藤秀則, 朝倉 晃, 岡村進介汪か：大腸多発癌の 臨床病理学的検討. 消外 $6: 1877-1881,1983$ 
8）井上 淳, 竹田力三, 宮野陽介ほか：大腸多発癌症 例の臨床的検討. 外科 $40: 865-870,1978$

9）貞広萿太郎, 近藤 喬, 武士昭彦汪か：大腸多発 癌, 重複癌の臨床的検討, 日本大腸肛門病会誌 $35: 524-529,1982$

10）友田博次, 古澤元之助, 大町彰二郎ほか：胃および 大腸に扎ける多発癌に関する検討. 外科 $41: 897$
-901, 1979

11）富田正雄, 三浦敏夫, 下山考俊ほか：大腸多発癌症 例の検討. 外科診療 $24: 1144-1148,1982$

12）貝原信明, 宮野陽介; 木村 修ほか：大腸癌手術に 打ける術中内視鏡検査. 日外会誌 $82 ： 1072$ $-1075,1981$ 